\title{
ENZYMATIC PURIFICATION OF GLUCOMANNAN FROM Amorphophallus oncophyllus USING a-AMYLASE
}

\author{
PURIFICAÇÃO ENZIMÁTICA DE GLUCOMANAN DE Amorphophallus oncophyllus \\ USANDO $\alpha$-AMILASAS
}

\author{
Dyah Hesti WARDHANI ${ }^{\text {*; }}$ José Antonio VÁZQUEZ² ${ }^{2}$ Dimas Akbar RAMDANI ${ }^{1}$; \\ Annisa LUTFIATI ${ }^{1}$; Nita ARYANTI ${ }^{1}$; Heri CAHYONO ${ }^{1}$ \\ 1. Department of Chemical Engineering, Diponegoro University, Jl. Prof. Soedharto, Kampus UNDIP Tembalang, Semarang 50275, \\ Indonesia; dhwardhani@undip.ac.id; 2. Grupo de Reciclado y Valorización de Materiales Residuales (REVAL)Instituto de \\ Investigacións Mariñas (CSIC) r/ Eduardo Cabello, 6. Vigo-36208. Galicia - Spain
}

\begin{abstract}
The international standards for top glucomannan flour require a minimum of $70 \%$ glucomannan. The glucomannan content of Amorphophallus oncophyllus flour was approximately 60\%, with starch as the major impurity. Elimination of starch was expected to increase the purity of glucomannan. The purpose of this research was to study starch hydrolysis of the flour using $\alpha$-amylase. Temperature (35.5$\left.84.5^{\circ} \mathrm{C}\right)$, time $(0.4-3.6 \mathrm{~h})$ and $\mathrm{pH}(2.2-8.8)$ of hydrolysis were selected as independent variables. A central composite design of response surface methodology (RSM) was performed to obtain the optimum condition. This approach was a novelty of this enzymatic purification of $A$. oncophyllus. Glucomannan content, starch content, and solubility were chosen as the response variables. The models were reliable for predicting the responses $\left(\mathrm{R}^{2} \geq 0.771\right)$. It was predicted that the highest glucomannan content $(93.0 \%)$ obtained at the lowest starch content $(1.14 \%)$, which hydrolysed at $\mathrm{pH} 6.17,84.5^{\circ} \mathrm{C}$ and $3.6 \mathrm{~h}$. Prior the verification of the optimum hydrolysed condition from the model, the glucomannan and starch content was $81.59 \%$ and $2.27 \%$, respectively. After purification, the absorbance of the $\beta-1,4$ glycosidic bond increased as a sign of higher glucomannan purity. A less rough surface and irregular shape of the grain morphology was observed after purification.
\end{abstract}

KEYWORDS: $\alpha$-amylase. Amorphophallus oncophyllus. Glucomannan. Hydrolysis. Purification. Response surface methodology

\section{INTRODUCTION}

Glucomannan is a non-ionic, water-soluble polysaccharide consisting of D-mannose and Dglucose connected with a $\beta-1,4$ linkage. The ratio between the monomers depends on the glucomannan source. The ratio between D-mannose and D-glucose from glucomannan of Amorphophallus konjac is 1.6, with light branches at the $\mathrm{C} 3$ of mannose through $\beta-1$, 6-glucosyl linkage (HARMAYANI et al., 2014). A small concentration of acetyl groups is found at the C-6 sugar position, ranging from 1 per 9 sugar units to 1 per 20 sugar units (CHUA et al., 2012). Glucomannan is known for its high viscosity, water absorption and swelling, which offer benefits in industrial applications of food and non-food products (ZHANG; YANG, 2014). Due to its unique rheological and gelling properties, glucomannan is widely employed as emulsifier and stabilizer in the food, drink, cosmetic and pharmaceutical industries. It also offers health benefits, such as anti-obesity, anti-inflammatory, and laxative effects as well as prebiotic activity
(CHUA et al., 2010). Modified glucomannan also has potency as a drug controlled release (WARDHANI et al., 2016a).

Amorphophallus oncophyllus, or porang tuber, is known to be a local glucomannan rich source that commonly grows in the Indonesia forest border. The calcium oxalate content has limited direct human consumption of the tuber due to its irritation effect in the mouth. Locally, the tuber only is proceed as dried chips and low-quality flour. Meanwhile, international standards require the top grade glucomannan flour containing at least $70 \%$ glucomannan (PEIYING et al., 2002). Hence, recent glucomannan flour from the A. oncophyllus does not met the international standards for the top grade.

Porang impurities that encapsulated the glucomannan granule (OHASHI et al., 2000) are dominated by starch (up to 10\%) (WARDHANI et al., 2017). The presence of starch, which interacts with glucomannan, affects its properties, reducing its viscosity and increasing its turbidity (XU et al., 2014). Therefore, it is necessary to eliminate this impurity to achieve a higher quality of glucomannan. 
Hydrolysis using $\alpha$-amylase has been applied to break starch down into smaller sugar units (ZHENG et al., 2015). Due to specific enzyme activity, $\alpha$-amylase only cleaves the $\alpha-1,4$ glycosidic linkage of starch and leaves the uncleaved $\beta-1,4$ glycoside of glucomannan. This disruption removes starch which encapsulates glucomannan granules, and release the granules subsequently. This purification process could affect the glucomannan properties as well as the scope of its applications.

There has been limited exploration on the application of enzymes in glucomannan purification. Therefore, the purpose of this study was to determine the enzymatic hydrolysis in purification of A. oncophyllus glucomannan using $\alpha$-amylase using response surface method (RSM) approach. The RSM consists of a group of mathematical and statistical procedures that can be used to study the interactions between the responses and a number of independent variables. The RSM is a popular and effective optimisation technique to analyse complex processes, including in extraction and hydrolysis application (WARDHANI et al., 2010; YI et al., 2012). In this study, the RSM was applied to investigate the relationship between the glucomannan content, starch content and solubility with independent hydrolysis variables, including the $\mathrm{pH}$, time and temperature. Functional groups and the morphology impact due to hydrolysis was also determined. This research was expected to obtain a method to produce a top grade of glucomannan flour via enzymatic hydrolysis using RSM approach, which was a novelty contribution of this research.

\section{MATERIALS AND METHODS}

Materials

Porang flour was obtained from a local market in Nganjuk, East Java (Indonesia). The flour contained glucomannan $(65.46 \%)$, starch (3.39\%), protein $(1.19 \%)$, fat $(0.15 \%)$, ash $(5.07 \%)$ and moisture (12.3\%). $\alpha$-amylase (EC 3.2.1.1) was isolated from Bacillus subtilis, provided by Suntaq International Limited. It has a working condition at $\mathrm{pH}$ 6.0-7.0, favourable at $\mathrm{pH} 6.0$ and $60-70^{\circ} \mathrm{C}$ with $2,000 \mathrm{U} / \mathrm{g}$ activity. A unit of the enzyme equals to the amount of enzyme which liquidizes $1 \mathrm{~g}$ of soluble starch at $60^{\circ} \mathrm{C}$ and $\mathrm{pH} 6.0$ in $1 \mathrm{~h}$. Additionally, 2-propyl alcohol solution (IPA, 70\%) was used for washing the solid cake after hydrolysis.

\section{Enzymatic hydrolysis}

Hydrolysis was conducted according to Wardhani's method (2017). A suspension of the flour $(2.5 \% \mathrm{w} / \mathrm{v})$ was prepared by diluting a predetermined amount of crude porang flour in 400 $\mathrm{mL}$ of distilled water. The starch of the crude flour was hydrolysed with $\alpha$-amylase $(0.03 \mathrm{~g} / \mathrm{g}$ flour $)$ under continuous stirring at $350 \mathrm{rpm}$ at the designated reaction conditions (Table 1). The variables and their range were selected base on Wardhani et al. (2016c) study. Once the reaction time was reached, the suspension was heated at $90^{\circ} \mathrm{C}$ for $15 \mathrm{~min}$ to inactivate $\alpha$-amylase before vacuumed filtered using Whatman paper no 1 . The solid cake was washed with IPA (200 mL, 70\%) and subsequently dried at $60^{\circ} \mathrm{C}$ and powdered using a house-hold blender (Philip HR 2860/80).

Table 1. Experimental domain and codification of independent variables in the factorial rotatable design.

\begin{tabular}{cccc} 
Coded values & \multicolumn{3}{c}{ Natural values } \\
\cline { 2 - 4 } & $\boldsymbol{T}\left({ }^{\mathbf{0}} \mathbf{C}\right)$ & $\boldsymbol{t}(\mathbf{h})$ & $\boldsymbol{p H}$ \\
\hline & & & \\
-1.63 & 35.5 & 0.4 & 3.2 \\
-1 & 45 & 1 & 5.5 \\
0 & 60 & 2 & 7.5 \\
+1 & 75 & 3 & 8.8
\end{tabular}

Codification: $V_{c}=\left(V_{n}-V_{0}\right) / \Delta V_{n}$; Decodification: $V_{n}=V_{0}+\left(\Delta V_{n} \mathrm{x} V_{c}\right) ; V_{n}=$ natural value of the variable to codify; $V_{c}=$ codified value of the variable; $V_{0}=$ natural value in the centre of the domain; $\Delta V_{n}=$ increment of $V_{n}$ for unit of $V_{c}$

\section{Glucomannan content}

Determination of glucomannan was performed using a modification of CHUA et al. method (2012). To obtain glucomanannan extract, the purification sample $(200 \mathrm{mg})$ was diluted with a formic acid-sodium hydroxide buffer $(0.1 \mathrm{M}, 50$ $\mathrm{mL}$ ) for $4 \mathrm{~h}$ at room temperature. The mixture was then diluted with the formic acid-sodium hydroxide buffer to $100 \mathrm{~mL}$ in a volumetric flask followed by 
centrifugation (4000 rpm, $15 \mathrm{~min}$ ) to obtain the extract.

To obtain the hydrolysate, the extract $(5.0$ $\mathrm{mL})$ and $\mathrm{H}_{2} \mathrm{SO}_{4}(3.0 \mathrm{M}, 2.5 \mathrm{~mL})$ was added to a $25-$ $\mathrm{mL}$ volumetric flask and hydrolysed for $90 \mathrm{~min}$ in a boiling water bath. After cooling, a $\mathrm{NaOH}$ solution (6.0 M, $2.5 \mathrm{~mL}$ ) was added. The mixture solution was diluted up to $25 \mathrm{~mL}$ with distilled water to form the glucomannan hydrolysate. The absorbance of both the glucomannan extract and the glucomannan hydrolysate at $550 \mathrm{~nm}$ was recorded, using distilled water as the blank. The content of glucose (mg) which corresponds with its absorbance was calculated from regression equation of the glucose standard curve. The glucomannan (GM) content was calculated according to Eq. [1]:

GM content $(\%)=\frac{5000 f\left(5 T-T_{0}\right)}{m}$

where, $f=$ correction factor $(=0.9), T=$ glucose content of glucomannan hydrolysate $(\mathrm{mg}), T_{0}=$ glucose content of glucomannan sample solution (mg) and $m=$ mass of the purified flour (200 mg).

\section{Starch content}

The starch analysis was performed base on Boil and Schaffer (1974). Samples (25 g) were dissolved in $30 \mathrm{~mL}$ of hot distilled water and gently boiled for $2 \mathrm{~min}$. The cooled solutions were diluted to $100 \mathrm{~mL}$ and subsequently filtered. Then, $20-\mathrm{mL}$ aliquots were withdrawn and mixed with $5 \mathrm{~mL}$ of a potassium iodate-acetic acid solution (0.3567 $\mathrm{g} \mathrm{KIO}$ $+57 \mathrm{~mL}$ glacial acetic acid made to $1 \mathrm{~L}$ ) and $0.5 \mathrm{~mL}$ $10 \%(\mathrm{w} / \mathrm{v})$ of freshly prepared potassium iodide was added to each sample to a total volume of $50 \mathrm{~mL}$. The colour was read at $600 \mathrm{~nm}$ compared to a blank solution.

\section{Determination of solubility}

Solubility of the samples was determined based on the method of Wang et al. (2014). The sample (1000 mg) was diluted with distilled water $(10 \mathrm{~mL})$ in a test tube and heated for $30 \mathrm{~min}$ at $60^{\circ} \mathrm{C}$ in a water bath. After centrifugation at $4000 \mathrm{rpm}$ for $20 \mathrm{~min}$, the supernatant was decanted in an evaporation dish and dried until the weight was constant. The solubility (\%) [Eq. 2] was calculated as follows:

$$
\text { Solubility }(\%)=\frac{\text { weight of } \text { dried supernatant }}{\text { volume of supernatant }}
$$

\section{IR spectra and morphology determination}

IR spectra and morphology determination of the samples followed Wardhani et al. (2016b). FTIR spectra of the powder samples were recorded under dry air conditions at room temperature in the range between $4000-400 \mathrm{~cm}^{-1}$ using IR Prestige Shimadzu. The observed peaks were assigned by comparison with the literature data. Meanwhile, for the morphology determination, the powder granule was observed using a SEM apparatus (FEI Inspect S50) at a certain magnification. Prior to SEM analysis, the dry sample was placed on a stub and coated with gold.

\section{Experimental design and statistical analysis}

To determine the enzymatic hydrolysis of glucomannan of A. oncophyllus, a set of 20 experimental points ( 6 replicates in the centre of the experimental domain) was studied following central composite design (BOX et al., 2005). The temperature $\left(T=35.5-84.5^{\circ} \mathrm{C}\right)$, time $(t=0.4-3.6 \mathrm{~h})$, and $\mathrm{pH}(\mathrm{pH}=2.2-8.8)$ were selected as independent variables, based on Wardhani et al. (2016c). The studied combination conditions of the independent variables and the encoding procedure of the variables are defined in Table 1. An orthogonal least-squares calculation was used to obtain polynomial equations that described the relationships between the dependent $(R)$ and the independent variables. The general form of the polynomial equations [Eq. 3] is:

$$
R=b_{0}+\sum_{i=1}^{n} b_{i} X_{i}+\sum_{\substack{i=1 \\ j>1}}^{n-1} \sum_{j=2}^{n} b_{i j} X_{i} X_{j}+\sum_{i=1}^{n} b_{i i} X_{i}^{2}
$$

where $R$ represents the responses to be modelled (glucomannan, starch content and solubility). $b_{0}$ is the constant coefficient, $b_{i}$ is the coefficient of linear effect, $b_{i j}$ is the coefficient of the interaction effect, $b_{i i}$ is the coefficient of the squared effect, $n$ is the number of variables and $X_{i}$ and $X_{j}$ are independent variables.

STATISTICA 10.0 was used to process the data and to estimate the coefficients of the regression equations. The equations were validated using analysis of variance (ANOVA) to determine the significance of each term in the fitted equations and to estimate the model goodness in each case. The best model with no significant lack-of-fit $(\mathrm{p}<0.05)$ and the highest correlation coefficient $\left(R^{2}\right)$ was selected. Eq. [3] was used to model the response surfaces for the studied variables. The surface plots were generated as a function of two independent variables, and the third variable was kept at the zero level.

\section{RESULTS AND DISCUSSION}

In this work, increasing the glucomannan content of A. oncophyllus flour was conducted by 
removing the starch using enzymatic hydrolysis. RSM was applied to obtain simultaneous effects of $\mathrm{pH}$, time and temperature on the hydrolysis as well as the optimum hydrolysis condition.

\section{Optimization of the enzymatic purification of glucomannan}

The observed and predicted responses of the designed experimental points of coded and uncoded variables are presented in Table 2. The experimental data of the design points showed that the results of the glucomannan content, starch content, and solubility varied in the ranges of $67.16-93.06 \%$, $1.24-3.29 \%$, and $0.104-0.935 \%$, respectively. The experimental maximum of glucomannan was achieved at the same condition as when the starch content was at a minimum. The observed data for the maximum glucomannan content $(93.06 \%)$ and lowest starch content $(1.24 \%)$ were obtained after purification at a $\mathrm{pH}$ of 5.5 and temperature of $60^{\circ} \mathrm{C}$ for $3.6 \mathrm{~h}$. This suggested that starch elimination improved the glucomannan purity. ANOVA was conducted to evaluate the polynomial model [3], which represents the interaction between independent variables in the responses. The quality of the model was assessed by the coefficient of determination $\left(\mathrm{R}^{2}\right), \mathrm{R}_{\text {adjusted, and its statistical }}^{2}$ significance was determined using Fisher's statistical test (F-test). The effect of the variables on the responses as well as the significance of the coefficient are presented in Table 3. A plot of the joint effects between the time and $\mathrm{pH}$ hydrolysis of glucomannan, starch content and solubility of purified glucomannan at a set temperature is presented in Figure 1. The surface contour of the plot showed different response trends as a function of the variables.

Table 2. Independent variables in the experimental design performed together with the observed and predicted data of glucomannan, starch content and solubility of the purified glucomannan from A. oncophyllus assisted by enzymatic hydrolysis.

\begin{tabular}{|c|c|c|c|c|c|c|c|c|c|}
\hline \multirow[t]{2}{*}{ Run } & \multirow[t]{2}{*}{$T_{c}$} & \multirow[t]{2}{*}{$t_{c}$} & \multirow[t]{2}{*}{$p H_{c}$} & \multicolumn{2}{|c|}{ Glucomannan } & \multicolumn{2}{|c|}{ Starch } & \multicolumn{2}{|c|}{ Solubility } \\
\hline & & & & observed & predicted & observed & predicted & observed & predicted \\
\hline 1 & -1 & -1 & -1 & 67.160 & 67.824 & 3.294 & 3.106 & 0.301 & 0.348 \\
\hline 2 & -1 & 1 & 1 & 74.377 & 77.185 & 2.476 & 2.241 & 0.322 & 0.355 \\
\hline 3 & 1 & -1 & 1 & 72.255 & 72.015 & 2.783 & 2.830 & 0.302 & 0.402 \\
\hline 4 & 1 & 1 & -1 & 78.623 & 82.510 & 2.373 & 2.204 & 0.554 & 0.588 \\
\hline 5 & 0 & 0 & 0 & 77.774 & 78.269 & 2.578 & 2.572 & 0.608 & 0.556 \\
\hline 6 & 0 & 0 & 0 & 79.047 & 78.269 & 2.680 & 2.572 & 0.567 & 0.556 \\
\hline 7 & -1 & -1 & 1 & 73.953 & 72.015 & 2.987 & 2.830 & 0.346 & 0.260 \\
\hline 8 & -1 & 1 & -1 & 74.377 & 76.087 & 2.680 & 2.402 & 0.489 & 0.364 \\
\hline 9 & 1 & -1 & -1 & 71.830 & 70.732 & 3.090 & 3.046 & 0.323 & 0.235 \\
\hline 10 & 1 & 1 & 1 & 84.566 & 85.612 & 1.760 & 1.670 & 0.935 & 0.833 \\
\hline 11 & 0 & 0 & 0 & 80.745 & 78.269 & 2.169 & 2.572 & 0.582 & 0.556 \\
\hline 12 & 0 & 0 & 0 & 77.349 & 78.269 & 2.783 & 2.572 & 0.500 & 0.556 \\
\hline 13 & -1.63 & 0 & 0 & 73.104 & 72.076 & 2.066 & 2.430 & 0.283 & 0.319 \\
\hline 14 & 1.63 & 0 & 0 & 82.868 & 81.332 & 1.862 & 1.915 & 0.669 & 0.617 \\
\hline 15 & 0 & -1.63 & 0 & 71.830 & 74.241 & 2.680 & 2.757 & 0.104 & 0.157 \\
\hline 16 & 0 & 1.63 & 0 & 93.057 & 88.082 & 1.248 & 1.588 & 0.491 & 0.522 \\
\hline 17 & 0 & 0 & -1.63 & 70.557 & 68.208 & 3.192 & 3.475 & 0.429 & 0.442 \\
\hline 18 & 0 & 0 & 1.63 & 74.377 & 74.163 & 2.680 & 2.814 & 0.500 & 0.570 \\
\hline 19 & 0 & 0 & 0 & 77.349 & 78.269 & 2.578 & 2.572 & 0.536 & 0.556 \\
\hline 20 & 0 & 0 & 0 & 76.5 & 78.269 & 2.783 & 2.572 & 0.567 & 0.556 \\
\hline
\end{tabular}

$T_{c}$ : value of codified temperature; $t_{c}$ : value of codified time; $p H_{c}:$ value of codified $\mathrm{pH}$.

The linear and quadratic terms of the $\mathrm{pH}$ effect were significant $(\mathrm{p}<0.05)$ for all responses, except solubility. Figure 1 confirms that the highest glucomannan content was observed with the combination of a moderate $\mathrm{pH}$ level and higher reaction level. Hydrolysis was conducted over a $\mathrm{pH}$ range of 3.5-7.5. Data from the enzyme vendor showed that the optimum working condition for the amylase was 5.0-6.5, which was in the middle of our working range. 
Table 3. The effect, coefficient and ANOVA analysis for the terms of the response surface equation.

\begin{tabular}{cccccccccc}
\hline & \multicolumn{3}{c}{ Glucomannan } & \multicolumn{3}{c}{ Starch } & \multicolumn{3}{c}{ Solubility } \\
\cline { 2 - 9 } Terms equation & Effect & Coeff. & p-value & Effect & Coeff. & $\begin{array}{c}\text { p- } \\
\text { value }\end{array}$ & Effect & Coeff. & $\begin{array}{c}\text { p- } \\
\text { value }\end{array}$ \\
\hline Mean/Interc. & $\mathbf{7 8 . 2 6 9}$ & $\mathbf{7 8 . 2 6 9}$ & $\mathbf{0 . 0 0 0}$ & $\mathbf{e}$ & $\mathbf{2 . 5 7 2}$ & $\mathbf{0 . 0 0 0}$ & $\mathbf{0 . 5 5 6}$ & $\mathbf{0 . 5 5 7}$ & $\mathbf{0 . 0 0 0}$ \\
$T$ & $\mathbf{5 . 6 6 7}$ & $\mathbf{2 . 8 3 3}$ & $\mathbf{0 . 0 0 1}$ & -0.316 & -0.158 & 0.051 & $\mathbf{0 . 1 8 3}$ & $\mathbf{0 . 0 9 6}$ & $\mathbf{0 . 0 0 0}$ \\
$T^{2}$ & -1.173 & -0.587 & 0.205 & $\mathbf{- 0 . 2 9 9}$ & $\mathbf{- 0 . 1 4 9}$ & $\mathbf{0 . 0 4 7}$ & $\mathbf{- 0 . 0 6 6}$ & $\mathbf{- 0 . 0 3 3}$ & $\mathbf{0 . 0 2 5}$ \\
$t$ & $\mathbf{8 . 4 7 4}$ & $\mathbf{4 . 2 3 7}$ & $\mathbf{0 . 0 0 0}$ & $\mathbf{- 0 . 7 1 5}$ & $\mathbf{- 0 . 3 5 8}$ & $\mathbf{0 . 0 0 1}$ & $\mathbf{0 . 2 2 4}$ & $\mathbf{0 . 0 1 2 4}$ & $\mathbf{0 . 0 0 0}$ \\
$t^{2}$ & $\mathbf{2 . 1 6 8}$ & $\mathbf{1 . 0 8 4}$ & $\mathbf{0 . 0 3 9}$ & $\mathbf{- 0 . 2 9 9}$ & $\mathbf{- 0 . 1 4 9}$ & $\mathbf{0 . 0 4 8}$ & $\mathbf{- 0 . 1 6 2}$ & $\mathbf{- 0 . 0 8 6}$ & $\mathbf{0 . 0 0 1}$ \\
$p H$ & $\mathbf{3 . 6 4 6}$ & $\mathbf{1 . 8 2 3}$ & $\mathbf{0 . 0 0 6}$ & $\mathbf{- 0 . 4 0 5}$ & $\mathbf{- 0 . 2 0 3}$ & $\mathbf{0 . 0 1 9 9}$ & $\mathbf{0 . 0 7 8}$ & $\mathbf{0 . 0 2 7}$ & $\mathbf{0 . 0 1 3}$ \\
$p H^{2}$ & $\mathbf{- 5 . 3 1 1}$ & $\mathbf{- 2 . 6 5 5}$ & $\mathbf{0 . 0 0 1}$ & $\mathbf{0 . 4 2 9}$ & $\mathbf{0 . 2 1 5}$ & $\mathbf{0 . 0 1 2 0}$ & -0.037 & -0.018 & 0.134 \\
$T x t$ & 1.758 & 0.879 & 0.195 & -0.069 & -0.035 & 0.709 & $\mathbf{0 . 1 6 8}$ & $\mathbf{0 . 0 8 8}$ & $\mathbf{0 . 0 0 1}$ \\
$T x p H$ & 1.002 & 0.501 & 0.437 & -0.187 & -0.093 & 0.330 & $\mathbf{0 . 1 2 7}$ & $\mathbf{0 . 0 6 0}$ & $\mathbf{0 . 0 0 5}$ \\
$t x p H$ & -1.546 & -0.773 & 0.243 & 0.057 & 0.028 & 0.754 & 0.039 & 0.019 & 0.199 \\
\hline
\end{tabular}

$T=$ temperature; $t=$ time; significant variable was printed in bold

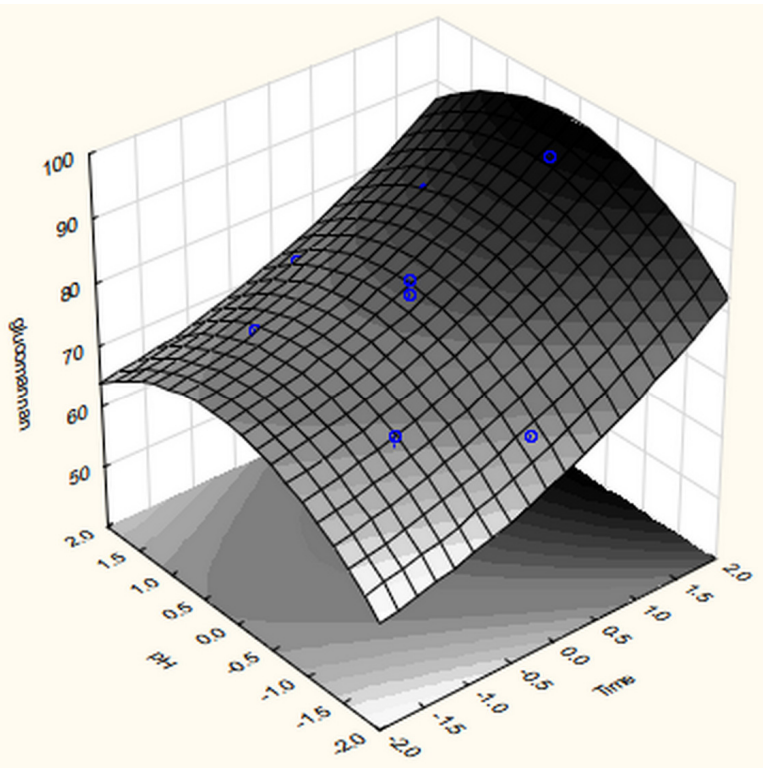

(A)

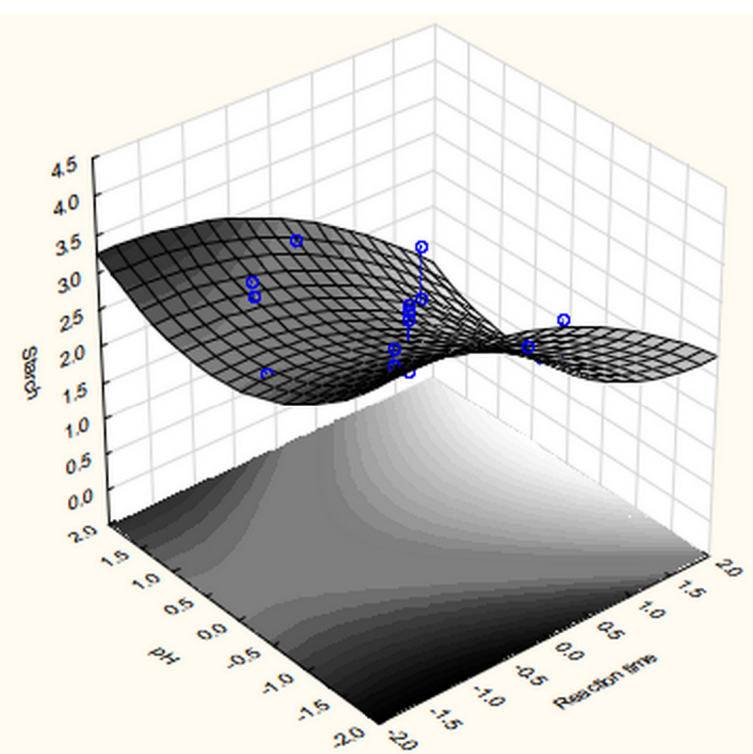


(B)

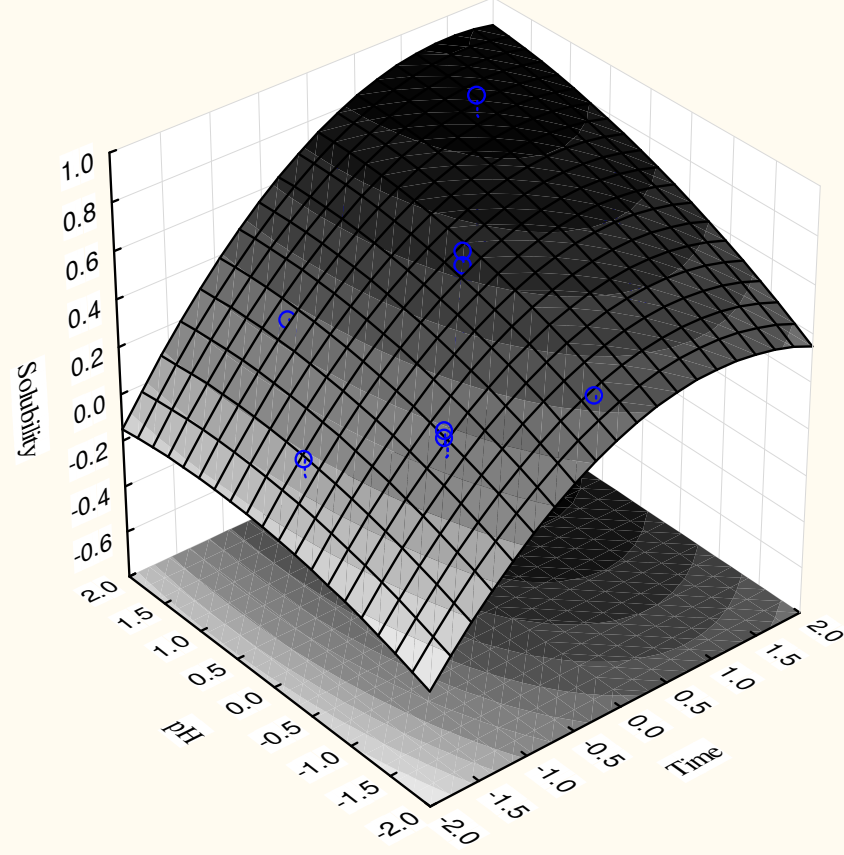

(C)

Figure 1. Response surfaces plotting the joint effect of $\mathrm{pH}$ and reaction time on glucomannan (A), starch (B), and solubility $(\mathrm{C})$ at a high level of temperature of the enzymatic reaction. The showed points are the experimental data.

Enzymes have a particular amino acid structure that contains active sites for catalysing reactions. $\mathrm{pH}$ affects the charge of amino acids at the active site as well as the shape of the active site. Once the active site changes shape, the substrate is no longer suitable to be bound in the active site of the altered enzyme. Moreover, the environmental acidity has an impact on the rate of enzyme protonation and deprotonation. The protonation and deprotonation rates are unique to the amino acid constituent, including the sequence and proportion of the enzyme, in response to environment conditions (OBOH; AKINDAHUNSI, 2001). Moreover, glucomannan can be hydrolysed at a lower $\mathrm{pH}$ level, which will decrease the glucomannan content. Hydrolysis of glucomannan using acid has been reported by Wang et al. (2015) and Tanaka et al. (2013). Hence, a pH in the middle of the hydrolysis range should be the favoured condition for hydrolysing starch and obtaining a higher glucomannan content.

The linear and quadratic coefficients of time were significant variables for the glucomannan and starch contents. A linear temperature range was significant for the glucomannan content and solubility, while a quadratic of the temperature was only significant for the starch content. The only significant linear interaction between temperature and time was observed for solubility. Hence, a new, simpler model was formulated for the responses by only considering the significant variables, while all of the insignificant variables were pooled into an error term (DOS SANTOS et al., 2012). Based on the data from Table 3, the new formula of the mathematical model for the corresponding variables in coded terms is presented in Table 4 (top). 
Table 4. Polynomial equations describing glucomannan content, starch, and solubility of purified glucomannan as a function of the coded independent variables (top) and experimental optimal conditions of temperature, time of reaction and $p H\left(T_{o p t}, t_{o p t}, p H_{o p t}\right)$ in which the maximum responses (glucomannan: $G$, starch: $S t$ and solubility: $S$ ) are achieved. $R_{\max / \min }$ are the responses obtained in each optimal value (bottom).

\begin{tabular}{|c|c|c|c|c|}
\hline \multicolumn{3}{|c|}{ Polynomial equations (in coded variables) } & $\mathbf{R}^{2}$ & $\mathbf{R}_{\text {adjusted }}^{2}$ \\
\hline \multicolumn{3}{|c|}{$\begin{array}{l}\text { Glucomannan content }(\%)= \\
78.269+2.833 T+4.237 t+1.084 t^{2}+1.823 p H-2.655 p H^{2}\end{array}$} & 0.866 & 0.746 \\
\hline \multicolumn{3}{|c|}{$\begin{array}{l}\text { Starch content }(\mathrm{g} / \mathrm{g})= \\
2.572-0.149 T^{2}-0.358 t-0.149 t^{2}-0.202 p H+0.215 p H^{2}\end{array}$} & 0.826 & 0.669 \\
\hline \multicolumn{3}{|c|}{$\begin{array}{l}\text { Solubility }(\%)= \\
0.557+0.096 T+0.124 t+0.027 p H+0.088 T t+0.060 T p H-0.086 t^{2}-0.033 T^{2}\end{array}$} & 0.771 & 0.565 \\
\hline & $\begin{array}{l}\text { Glucomannan } \\
\quad \boldsymbol{G}(\%)\end{array}$ & $\begin{array}{l}\text { Starch } \\
\text { St }(\%)\end{array}$ & & $\begin{array}{l}\text { Solubility } \\
S(\%)\end{array}$ \\
\hline $\begin{array}{l}T_{\text {opt }}\left({ }^{0} \mathrm{C}\right) \\
t_{\text {opt }}(\mathrm{h}) \\
p \boldsymbol{H}_{\text {opt }} \\
\boldsymbol{R}_{\text {max } / \text { min }}\end{array}$ & $\begin{array}{c}G \text { increases with } T \\
G \text { increases with } t \\
6.17 \\
93.0 \%\end{array}$ & $\begin{array}{c}\text { St decreases with } T \\
S t \text { decreases with } t \\
6.42^{*} \\
1.14(\mathrm{~g} / \mathrm{g})^{*}\end{array}$ & \multicolumn{2}{|c|}{$\begin{array}{c}S \text { increases with } T \\
2.48 \mathrm{~h} \\
S \text { increases with } p H \\
0.94 \%\end{array}$} \\
\hline
\end{tabular}

$\mathbf{T}=$ temperature $\left({ }^{\mathbf{O}} \mathrm{C}\right) ; \mathrm{t}=$ time $(\mathbf{h}) ; \mathbf{R}=$ response; $*$ minima values

Extension of the reaction period resulted in greater glucomannan purification. A longer reaction time allowed the enzyme to hydrolyse more starch, resulting in a lower starch concentration. This result was supported by Fadilah et al. (2015), who reported that the liberation of a reducing sugar increased because of a longer hydrolysis time of porang flour. Although a longer reaction time allowed for a higher glucomannan content, the reaction should be time-limited for efficiency. Lopez et al. (2006) reported that $90 \%$ starch was hydrolysed within $2 \mathrm{~h}$. However, complete hydrolysis was still not achieved even after $48 \mathrm{~h}$ of incubation (LOPEZ et al., 2006). Another consideration in designing the reaction period was the competition between substrates for occupying the enzyme. Increasing accumulation of the reducing sugar in the reaction medium during the hydrolysis of starch led to a significant decrease in the hydrolysis rate due to its competition with starch for occupying the active sites of $\alpha$-amylase (KOLUSHEVA; MARINOVA, 2007).

The $\mathrm{R}^{2}$ and $\mathrm{R}_{\text {adjusted }}^{2}$ of each model were obtained by applying regression analysis (Table 4, bottom). $\mathrm{R}^{2}$ shows how well the model fits the experimental data. Less difference between the predicted and actual values was observed when the model fit most of the observed data. In this observation, the value of $\mathrm{R}^{2}$ approached unity (KUMAR et al., 2013). Table 4 (bottom) shows that the $\mathrm{R}^{2}$ of the models were higher than 0.771 . This indicated that the variations in the dependent variables in this study could be explained by the model minimum of $77.1 \%$. ROSLAN et al. (2014) suggested that the $\mathrm{R}^{2}$ should be greater than 0.80 to obtain a good fit model. Because some variables were insignificant, $R^{2}$ was modified to $R_{\text {adjusted }}^{2}$ to accommodate the significant variables alone. The value of $\mathbf{R}_{\text {adjusted }}$ was reduced when more variables were involved in the model. The maximum difference between the $\mathrm{R}^{2}$ and $\mathrm{R}_{\text {adjusted }}$ of the models in this study was 0.1858 . This suggested that the model was only unable to explain $18.35 \%$ of the total variation in data, indicating that the observed and predicted data were in reasonable agreement. A model is recommended as acceptable when the difference between the $\mathrm{R}^{2}$ and $\mathrm{R}_{\text {adjusted }}^{2}$ is less than 0.2 . When the difference is more than 0.2 , there could be a problem with either the data or the chosen model (DELGADO et al., 2009).

In this study, the focus of hydrolysis was to obtain the highest glucomannan concentration. By applying the partial derivation of variables as decribed previously (WARDHANI et al., 2010 and VÁZQUEZ et al., 2016) on the glucomannan model, the optimum glucomannan content $(93.0 \%)$ could be predicted to be obtained at $p H=6.17$ at a higher temperature and longer hydrolysis time (Table 4, bottom). A high glucomannan content was observed when hydrolysis was conducted at a moderate $\mathrm{pH}$ and long reaction time. Interestingly, the lowest starch content was observed close to predicted value 
for the highest glucomannan conditions. Because this $\mathrm{pH}$ range was close to the moderate $\mathrm{pH}$ level that was studied, more starch degradation was observed at $p H=6.42$. This suggested that the high glucomannan content was achieved by removing impurities, including starch, which was the major contaminant. Therefore, the lowest starch content $(1.14 \%)$ was obtained at $p H=6.42$ at a higher temperature and longer hydrolysis time (Table 4 bottom). The hydrogen bond interaction was the main interaction between glucomannan and starch. The interaction between starch and glucomannan influenced the functional properties of glucomannan (XU et al., 2014). The absence of starch helps to increase the solubility of the purified sample. The solubility of purified glucomannan was in line with the glucomannan purity. It has been reported that an acetyl group, found at the C-6 sugar position of glucomannan (CHUA et al., 2012) is a functional group that is responsible for glucomannan solubility (BEHERA; RAY, 2016). Increasing the glucomannan content meant more acetyl groups were available for glucomannan solubility.

\section{IR characterization}

Figure 2 describes the functional group comparison of the crude porang flour, sample with the highest glucomannan content and the optimized sample. In general, these samples had a similar typical peak number of functional groups, but the intensities of the peaks differed. The spectra were in good agreement with those reported by CHUA et al. (2012).

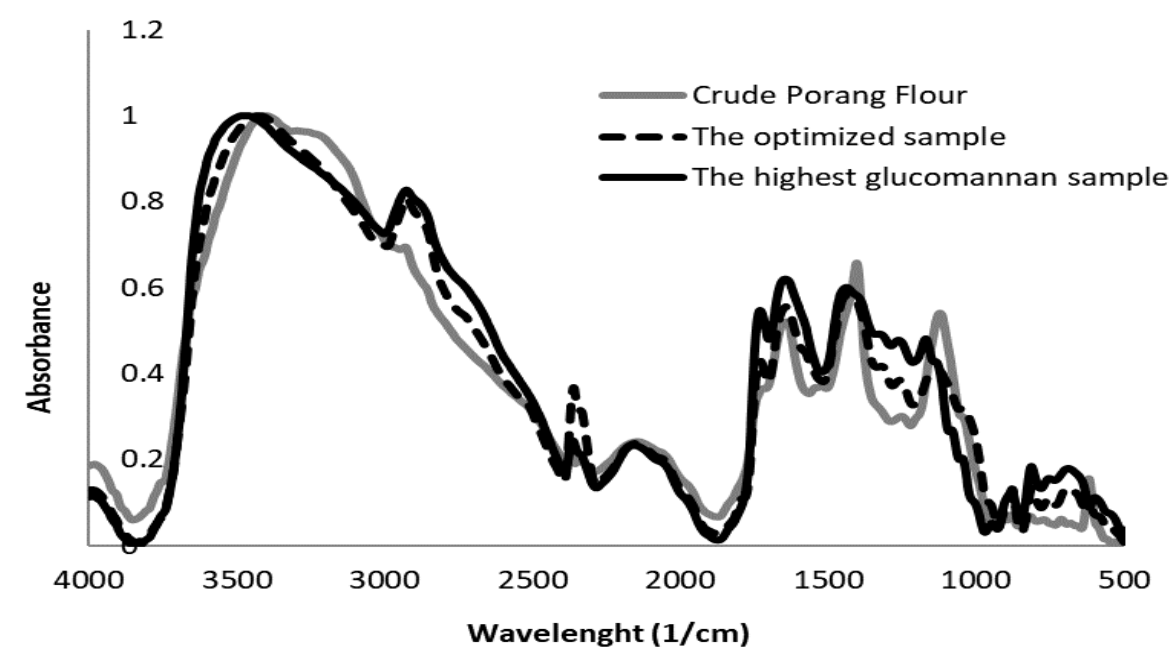

Figure 2. Functional group comparison of crude porang flour (grey solid line), observed sample with the highest glucomannan content (black solid line), and the optimised condition sample (black dash line) (top)

All samples showed a wide peak for the O$\mathrm{H}$ groups of glucomannan located at $3000-3700 \mathrm{~cm}^{-1}$ (ZHANG et al., 2001). Methyl groups located at $\sim 2900 \mathrm{~cm}^{-1}$ were assigned to the $-\mathrm{CH}$ stretch vibration, and the carbonyl at $1720 \mathrm{~cm}^{-1}$ was assigned to the acetyl groups in glucomannan (LIU et al., 2015). Figure 2 supports that the higher solubility of the purified sample was due to the higher absorbance of the acetyl groups in the purified flour compared to the crude flour. The existence of the $\beta-1,4$ linked glucose and mannose of glucomannan was indicated by the carbonyl $(\mathrm{C}=\mathrm{O})$ stretch vibration located at $\sim 1650 \mathrm{~cm}^{-1}$ (WIDJANARKO et al., 2011). Peaks at $\sim 1150$ and $\sim 1050 \mathrm{~cm}^{-1}$ referred to C-O-C stretch vibrations from the ether groups in the pyranose rings, indicating the presence of $\beta-1,4$ glucosidic and $\beta-1,4$ mannosidic linkages in glucomannan (FRANCO et al., 1992). Nikonenko et al. (2002) reported that the spectra of $\alpha$ - and $\beta$-D-glucose were in the 1200-920 $\mathrm{cm}^{-1}$ range. The distinct peaks for the glycosidic linkage of amylose and cellulose are present at $1175-1140$ and $1000-970 \mathrm{~cm}^{-1}$, respectively. The $\beta$ configuration of the glycosidic linkage of cellulose appears to be a combination of several absorption bands instead of the single band observed in the monomer $\beta$-D-glucose spectrum. Compared to the $\alpha$-D-glucose spectrum, the number of bands in the amylose spectrum ( $\alpha$ configuration of the glycosidic linkage) remained unchanged (NIKONENKO et al., 2002).

\section{Grain Morphology}


A morphological evaluation was conducted to investigate the effect of hydrolysis on the microstructure of glucomannan granules. Figure 3 shows the granule morphology comparison of crude porang flour and the highest purity glucomannan sample at different magnifications. Crude flour has a regular, relatively uniform shape with oval granules. The outward appearance of this granule has a rough surface, which could be from impurities (mainly starch). This observation was in accordance with a report by Ohashi et al. (2000) who showed that glucomannan granules were encapsulated by impurities, including starch, cellulose, and nitrogencontaining material.
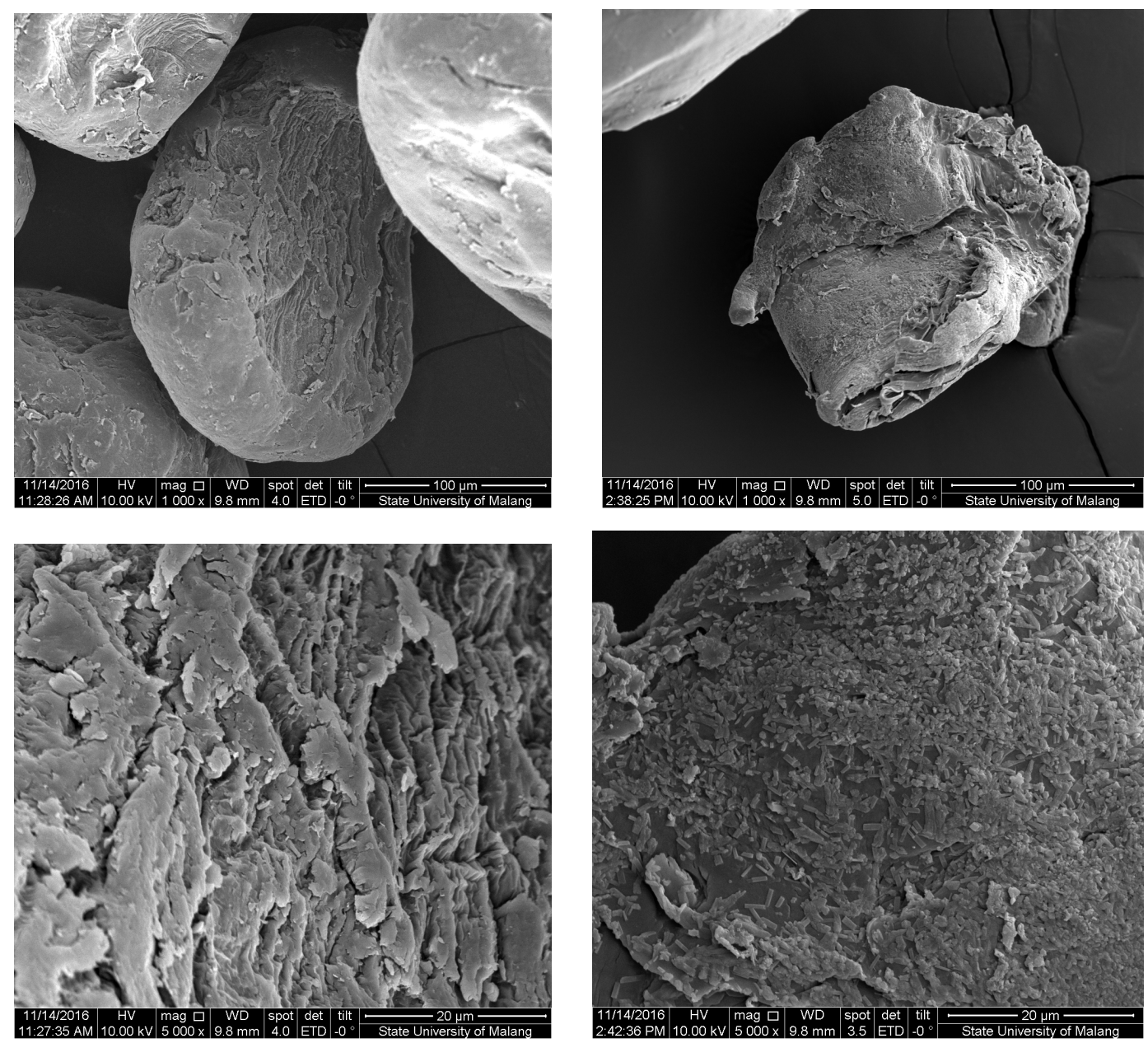

Figure 3. Scanning electronic microscopic images of the crude flour (left) and the highest glucomannan content sample (right)

Meanwhile, the morphology of the purified sample had a less rough surface and irregularly shaped of granule after hydrolysis. This less rough surface could be due to the liquefaction effect of starch during hydrolysis as well as the removal of impurities by enzymatic hydrolysis. This removal resulted in a significant increase in the glucomannan content of the flour. The hydrolysed sample also had a larger size granule than the crude samples. This hydrolysis was conducted in a water system. We observed that this dried solid was very difficult to grind using a house-hold blender, resulting in a larger, heterogeneous size powder. A similar phenomenon was also reported by Tatirat et al. (2012) and Wardhani et al. (2016b).

\section{CONCLUSION}

Enzymatic hydrolysis helped to purify glucomannan of porang flour by removing the impurities. The highest glucomannan concentration was observed at the lowest starch concentration of the sample. Increasing the glucomannan content drove sample solubility. The model was sufficiently reliable to predict the responses $\left(R^{2} \geq 77.1 \%\right)$. It was predicted that the highest glucomannan content was 
$93 \%$, which was obtained at $84.5^{\circ} \mathrm{C}$, for $3.6 \mathrm{~h}$ and at $\mathrm{pH}$ value of 6.17. However, the verified glucomannan and starch content were $81.59 \%$ and $2.27 \%$, respectively. The absorbance level of the $\beta$ 1,4 glycosidic bond improved after purification, supporting the increase in glucomannan content. Morphology analysis confirmed that removal of the impurities smoothened the grain surface.

\section{ACKNOWLEDGMENT}

This research was funded by Directorate of Research and Community Service, Directorate General of Higher Education, Ministry of Research, Technology and Higher Education of the Republic of Indonesia through Fundamental Scheme (Grant no. 181-42/UN7.5.1/PG/2016).

RESUMO: Os padrões internacionais para a farinha de alta calidade de glucomanan requerem um mínimo de 70\% de glucomanan. O conteúdo de glucomanano da farinha de Amorphophallus oncophyllus foi de aproximadamente $60 \%$, com o amido como a maior impureza. Esperava-se que a eliminação do amido aumentasse a pureza do glucomanan. O objetivo desta pesquisa foi estudar a hidrólise do amido da farinha usando $\alpha$-amilase. A temperature $\left(35,5-84,5^{\circ} \mathrm{C}\right)$, o tempo $(0,4-3,6 \mathrm{~h})$ e o $\mathrm{pH}(2,2-8,8)$ da hidrólise foram selecionados como variáveis independentes. Um desenho central composto pertencente á metodologia da superfície de resposta (MSR) foi realizado para obter a condição ótima. Esta abordagem foi uma novidade desta purificação enzimática de $A$. oncophyllus. O conteúdo de glucomanan, conteúdo de amido e solubilidade foram escolhidos como as respostas. Os modelos foram confiáveis para predizer as respostas $\left(R^{2} \geq 0,771\right)$. Os modelos indicaram que o maior conteúdo de glucomanan $(93,0 \%)$ foram obtidos no menor conteúdo de amido $(1,14 \%)$, que hidrolisou a um $\mathrm{pH} 6,17,84,5^{\circ} \mathrm{C}$ e $3,6 \mathrm{~h}$. Antes da verificação da condição hidrolisada ótima do modelo, o conteúdo de glucomanan e amido foi de $81,59 \%$ e 2,27\%, respectivamente. Após a purificação, a absorbância da ligação $\beta-1,4$ glicosídica aumentou com um sinal de maior pureza de glucomanan. Uma superfície mais lisa e forma irregular da morfologia do grão foi observada após a purificação.

PALAVRAS-CHAVE: $\alpha$-amilasa. Amorphophallus oncophyllus. Glucomanan. Hidrólise. Purificação. Metodologia da superfície de resposta

\section{REFERENCES}

BEHERA, S. S.; RAY, R. C. Konjac glucomannan, a promising polysaccharide of Amorphophallus konjac K. Koch in health care. Int. J. Biol. Macromol., v. 92, p. 942-956, 2016. https://doi.org/10.1016/j.ijbiomac.2016.07.098

BOIL, P. G. M. D.; SCHAFFLER, K. J. A simplified starch determination for raw sugars. Proceedings of the South African Sugar Technologists' Association, 1974. p. 39-41.

BOX, G. E. P.; HUNTER. J. S.; HUNTER, W. G. Statistics for experimenters: design, innovation, and discovery. 2 ed. New Jersey: John Wiley \& Sons, 2005.

CHUA, M.; BALDWIN, T. C.; HOCKING, T. J.; CHAN, K. Traditional uses and potential health benefits of Amorphophallus konjac K. Koch ex N.E.Br. J. Ethnopharmacol., v. 128, p. 268-278, 2010. https://doi.org/10.1016/j.jep.2010.01.021

CHUA, M.; CHAN, K.; HOCKING, T. J.; WILLIAMS, P. A.; PERRY, C. J.; BALDWIN, T. C. Methodologies for the extraction and analysis of konjac glucomannan from corms of Amorphophallus konjac $K$.

Koch. Carbohydr. Polym., v. 87, p. 2202-2210, 2012. https://doi.org/10.1016/j.carbpol.2011.10.053

DELGADO, R.; CASTRO, A. J.; VÁZQUEZ, M. A kinetic assessment of the enzymatic hydrolysis of potato (Solanum tuberosum). LWT-Food Sci. Technol., v. 42, p. 797-804, 2009. 
DOS SANTOS, T. C.; GOMES, D. P. P.; BONOMO, R. C. F.; FRANCO, M. Optimization of solid state fermentation of potato peels for the production of cellulolytic enzymes. Food Chem., v. 13, p. 1299-1304, 2012. https://doi.org/10.1016/j.foodchem.2011.11.115

FADILAH; ROCHMADI; SYAMSIAH, S.; HARYADI. Hydrolysis of starch in porang flour using alpha amylase. J. Eng. Sci. Technol., v. 10. p. 1-8, 2015.

FRANCO, C. M.; DO RIO PRETO, S. J.; CIACCO, C. F. Factors that affect the enzymatic degradation of natural starch granules effect of the size of the granules. Starch/Stärke, v. 44.p. 422-426, 1992. https://doi.org/10.1002/star.19920441106

HARMAYANI, E.; APRILIA, V.; MARSONO, Y. Characterization of glucomannan from Amorphophallus oncophyllus and its prebiotic activity in vivo. Carbohydr. Polym., v. 112. p. 475-479, 2014. https://doi.org/10.1016/j.carbpol.2014.06.019

KOLUSHEVA, T.; MARINOVA, A. A study of the optimal conditions for starch hydrolysis through thermostable $\alpha$-amylase. J. Univ. Chem. Technol. Metall., v. 42. p. 93-96, 2007.

KUMAR, A.; KUMAR, V.; KUMAR, J. Multi-response optimization of process parameters based on response surface methodology for pure titanium using WEDM process. Internat. J. of Adv. Manufact. Technol., v. 68. p. 2645-2668, 2013. https://doi.org/10.1007/s00170-013-4861-9

LIU, J.; XU, Q.; ZHANG, J.; ZHOU, X.; LYU, F.; ZHAO, P.; DING, Y. Preparation, composition analysis and antioxidant activities of konjac oligo-glucomannan. Carbohydr. Polym., v. 130. p. 398-404, 2015. https://doi.org/10.1016/j.carbpol.2015.05.025

LÓPEZ, C.; TORRADO, A.; FUCIÑOS, P.; GUERRA, N. P.; PASTRANA, L. Enzymatic inhibition and thermal inactivation in the hydrolysis of chestnut purée with an amylases mixture. Enzyme Microb. Technol., v. 39. p. 252-258, 2006. https://doi.org/10.1016/j.enzmictec.2005.10.012

NIKONENKO, N. A.; BUSLOV, D. K.; SUSHKO, N. I.; ZHBANKOV, R. G. Analysis of the structure of carbohydrates with use of the regularized deconvolution method of vibrational spectra. Balıkesir Üniversitesi Fen Bilimleri Enstitüsü Dergisi, v. 4, p. 13-16, 2002.

OBOH, G.; AKINDAHUNSI, A. A. Physico-chemical studies on amylases from fermented cassava waste water (No. IC--2001/113). Abdus Salam International Centre for Theoretical Physics. v. 33. p. 1-14, 2001.

OHASHI, S.; SHELSO, G., J.; MOIRANO, A. L.; DRINKWATER, W. L. Clarified konjac glucomannan. United States Patent 6162906, 2000.

PEIYING, L. S.; ZHANG, G.; ZHU, Y.; CHEN, Q. H.; HAN, M.; WANG, Z.; XIONG W.; PENG, H. Konjac flour. Professional standard of the people Republic of China for konjac flour (NY/T 494). Beijing: Ministry of Agriculture of P.R. of China. 2002.

ROSLAN, J.; KAMAL, S. M. M.; YUNOS, K. F. M.; ABDULLAH, N. Optimization of enzymatic hydrolysis of tilapia muscle (Oreochromis niloticus) using response surface methodology (RSM). Sains Malays., v. 43. p. 1715-1723, 2014.

TANAKA, Y.; OKAMOTO, K.; MATSUSHIMA, A.; OTA, T.; MATSUMOTO, Y.; AKASAKI, T. Microwave-assisted acid hydrolysis of konjac products for determining the konjac powder content. Anal. Sci., v. 29, p. 1049-1053, 2013. https://doi.org/10.2116/analsci.29.1049

TATIRAT, O.; CHAROENREIN, S.; KERR, W.L. Physicochemical properties of extrusion-modified konjac glucomannan. Carbohydr. Polym., v. 87. p. 1545-1551, 2012. https://doi.org/10.1016/j.carbpol.2011.09.052

VÁZQUEZ, J. A.; BLANCO, M.; FRAGUAS, J.; PASTRANA, L.; PÉREZ-MARTÍN, R. I. Optimization of the extraction and purification of chondroitin sulphate from head by-products of Prionace glauca by environmental friendly processes. Food Chem., v. 198. p. 28-35, 2016.

https://doi.org/10.1016/j.foodchem.2015.10.087 
WANG, J.; LIU, C.; SHUAI, Y.; CUI, X.; NIE, L. Controlled release of anticancer drug using graphene oxide as a drug-binding effector in konjac glucomannan/sodium alginate hydrogels. Colloids Surf. B, v. 113. p. 223229, 2014. https://doi.org/10.1016/j.colsurfb.2013.09.009

WANG, S.; ZHOU, B.; WANG, Y.; LI, B. Preparation and characterization of konjac glucomannan microcrystals through acid hydrolysis. Food Res. Int., v. 67. p. 111-116, 2015.

https://doi.org/10.1016/j.foodres.2014.11.008

WARDHANI, D. H.; VÁZQUEZ, J. A.; PANDIELLA, S. S. Optimization of antioxidants extraction from fermented soybeans by Aspergillus oryzae. Food Chem., v. 118. p. 731-739, 2010.

https://doi.org/10.1016/j.foodchem.2009.05.057

WARDHANI, D. H.; ABDULLAH, AZIZAH, A. N.; ANANTA, M. Y. Physicochemical properties of acetylated glucomannan of Amorphophallus onchophillus as excipient of drug controlled release. AIP Conf. Proc., v. 1746, p. 020039-1-020039-8. 2016a. https://doi.org/10.1063/1.4953964

WARDHANI, D. H.; NUGROHO, F.; MUSLIHUDIN, M.; ARYANTI, N. Application of response surface method on purification of glucomannan from Amorphophallus oncophyllus by using 2-Propanol. Sci. Study Res. Chemist. Chemic. Eng. Biotechnol. Food Indust., v. 17. p. 63-74, 2016 b.

WARDHANI, D. H.; ARYANTI, N.; MURFIANTO, F.; YOGANANDA, K. D. Quality improvement of glucomannan from Amorphophallus oncophyllus by using $\alpha$-amylase. Inovasi Teknik Kimia, v. 1, p. 71-77, 2016c.

WARDHANI, D. H.; ARYANTI, N.; RAMDANI, D. A.; LUTFIATI, A. Swelling capacity of glucomannan from Amorphophallus oncophyllus purified with enzymatic hydrolysis. Adv. Sci. Lett., v. 23.p. 5623-5625, 2017. https://doi.org/10.1166/asl.2017.8784

WIDJANARKO, S. B.; SUTRISNO, A.; FARIDAH, A. $\mathrm{H}_{2} \mathrm{O}_{2}$ effect on physicochemical characteristics of porang flour (Amorphophallus oncophyllus) by using maceration and ultrasound. Jurnal Teknologi Pertanian, v. 12. p. 143-152, 2011.

XU, W.; WANG, S.; YE, T.; JIN, W.; LIU, J.; LEI, J.; LI, B.; WANG, C. A simple and feasible approach to purify konjac glucomannan from konjac flour-Temperature effect. Food Chem., v. 158. p. 171-176, 2014. https://doi.org/10.1016/j.foodchem.2014.02.093

YI, C.; LI, X.; SUN, P.; HE, Y. Response surface optimization and characteristics of Indica rice starch-based fat substitute prepared by $\alpha$-amylase. Starch-Stärke, v. 646. p. 503-509, 2012.

https://doi.org/10.1002/star.201100167

ZHANG, C.; YANG, F. Q. Konjac glucomannan, a promising polysaccharide for OCDDS. Carbohydr.

Polym., v. 104. p. 175-181, 2014. https://doi.org/10.1016/j.carbpol.2013.12.081

ZHANG, H.; YOSHIMURA, M.; NISHINARI, K.; WILLIAMS, M. A. K.; FOSTER, T. J.; NORTON, I.T. Gelation behaviour of konjac glucomannan with different molecular weights. Biopolymers, v. 59. p. 38-50, 2001. https://doi.org/10.1002/1097-0282(200107)59:1<38::AID-BIP1004>3.0.CO;2-A

ZHENG, Y.; LI, Y.; ZHANG, Y.; ZHANG, R.; ZHANG, Y.; ZHAO, S. Effects of limited enzymatic hydrolysis, $\mathrm{pH}$, ionic strength and temperature on physicochemical and functional properties of palm (Elaeis guineensis Jacq.) kernel expeller protein. J. Food Sci. Technol., v. 52. p. 6940-6952, 2015.

https://doi.org/10.1007/s13197-015-1839-7 